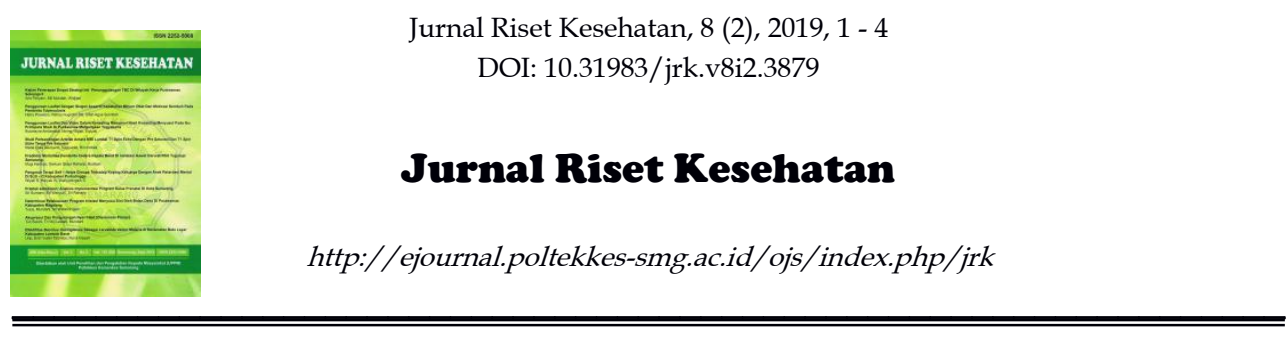

\title{
SELF-ACUPRESSURE TO LOWER BLOOD PRESSURE ON OLDER ADULTS WITH HYPERTENSION
}

\author{
Agus Citra Dermawan $^{\mathrm{a}}$; Santun Setiawati ${ }^{\mathrm{b}}$; Raden Siti Maryam ${ }^{\mathrm{c}^{*}}$ \\ ${ }^{a}$ Akademi Keperawatan Bina Insan ; Kramat Raya 22 ; Jakarta Utara ; Indonesia \\ b,c Poltekkes Kemenkes Jakarta III ; Melati 2 ; Bekasi ; Indonesia
}

\begin{abstract}
Hypertension is often suffered by older adults, which directly can impact their health and quality of life. One of the non-pharmacological management for patients with hypertension is through acupressure to accelerate blood-flow circulation and to reduce blood pressure. This study aims to determine the self-acupressure effect on the elderly with hypertension in Cilincing Health Center in North Jakarta. This research used a quasi-experimental involving control and intervention group. Thirty-six elderlies were involved in this study divided into two groups. Findings showed that there were significant differences in the intervention group between the results of systolic and diastolic measurements before and after acupressure ( $p$-value $=0.000$ ). The findings suggest that families can apply self-acupressure as a support system for older adults with hypertension.
\end{abstract}

Keywords: self-acupressure ; hypertension in older adults ; family

\section{Introduction}

Life expectancy among older adults sometimes is being hampered by various health problems. The top five diseases often suffered by older adults are hypertension, arthritis, stroke, chronic obstructive pulmonary disease (COPD), and diabetes mellitus (DM) (Riskesdas, 2013). Hypertension is considered to be the most suffered disease among older adults, as approximately around $16-31 \%$ of senior citizens in Indonesia from various states or provinces from hypertension (Riskesdas RI, 2013). The elderly with hypertension have a higher chance of getting a complication. The most often occurred complication on the elderly with hypertension is cardiovascular disease and stroke. Untreated hypertension can cause daze, throbbing pain on sub occipital, numbness series, or paralysis on one entire side of the body. The non-pharmacological treatments for hypertension can be through some specific techniques in reducing stress, techniques in

\footnotetext{
${ }^{*}$ ) Corresponding Author (Raden Siti Maryam)
}

E-mail: raden.maryam@poltekkesjakarta3.ac.id losing weight, alcohol, doing physical exercises, relaxation, and acupressure (Rezky, Hasneli, \& Hasanah, 2015).

Acupressure or administering pressure on specific points on the body is one of the non-pharmacological interventions that are very efficient and relatively safe because it does not involve invasive actions or injuring the skin (Saputra, 2002). The benefits of acupressure include helping to manage stress, calm nervous tension, and increase body relaxation. This therapeutic technique uses fingers performed at points associated with hypertension. Administering massages on specific spots in acupressure therapy can stimulate nerve waves so that they can accelerate blood-flow circulation, relax spasms, and lower blood pressure (Hartono, 2012). Acupressure can be done with the help of others or done independently. The elderly with family assistance are expected to be able to do acupressure independently. Research by Widodo et al. (2014) shows that 
acupressure performed in hypertensive patients can lower blood pressure. Rezky, Hasneli, and Hasanah (2015) explain that reflexology can reduce blood pressure. Treating hypertension is not only using medical drugs but can use Benson relaxation therapy regularly (Purwati, Suryani \& Supriyono, 2011).

Acupressure is one of the non-pharmacological treatments with methods, tools, or materials applied in medical care, which can be administered as an alternative or complementary to specific medical treatments (Kozier, Erb, Berman, \& Snyder, 2010). The right alternative to reduce blood pressure without drug dependence and side effects is to use non-pharmacological treatments (Kowalski, 2010). Therefore, this study aims to determine the effect of independent acupressure on elderly blood pressure in the community.

\section{Method}

The study design used quasi-experimental with intervention and control groups. The intervention group received acupressure; meanwhile, the control group did not receive it.The sampling technique used was consecutive sampling done by selecting all individuals who had met the selection criteria until the desired number of samples meet the requirement. The number of samples in this study was 36 elderly (18 elderly in the intervention group and 18 elderly in the control group). Data collection was carried out with respondents filling out questionnaire sheets, conducting blood pressure checks (pre) done by researchers, administering acupressure guided by researchers once for 30 minutes, and finally conducting blood pressure re-checks (post).

This study used ethical considerations with the intention that respondents get protection on rights and privacy during data collection. The researchers proposed informed consent, which aimed at maintaining the privacy of respondents, respecting the autonomy of respondents, maintaining the comfort of respondents. This study had been approved by the Ethics Commission of the Polytechnic of the Ministry of Health Jakarta III No. KEPK-PKKJ3 / 050 / XII / 2017. In bivariate analysis, a dependent test was used to determine the effect of independent acupressure on elderly blood pressure.

\section{Result and Discussion}

Fifteen elderlies in the intervention group are aged between $60-70$ years old, while there are twelve in the control group. Women are dominating the intervention group in which there are 14 people $(77.8 \%)$; meanwhile, the control group is dominated by men in which there are ten elderlies $(55.6 \%)$. The educational background of the elderly is mostly graduated from elementary school in which there are eight people for each group, and most of the elderly are unemployed.

Table 1. Characteristics of elderlies blood pressure before intervention between the two groups.

\begin{tabular}{lcccc}
\hline Variable & \multicolumn{2}{c}{$\begin{array}{c}\text { Intervention } \\
\text { Group }\end{array}$} & \multicolumn{2}{c}{ Control Group } \\
\hline Blood & $\mathrm{N}$ & $\%$ & $\mathrm{~N}$ & $\%$ \\
Pressure & & & & \\
Systolic & & & & \\
$140-159$ & 11 & 61.1 & 8 & 44.5 \\
$160-179$ & 5 & 27.8 & 7 & 38.9 \\
$180-209$ & 2 & 11.1 & 2 & 11.1 \\
$\geq 210$ & - & - & 1 & 5.5 \\
& & & & \\
Diastolic & & & 4 & \\
$70-80$ & 4 & 22.2 & 9 & 22.2 \\
$90-99$ & 6 & 33.4 & 3 & 50.0 \\
$100-109$ & 7 & 38.9 & 1 & 16.8 \\
$110-119$ & 1 & 5.5 & 1 & 5.5 \\
$\geq 120$ & - & - & & 5.5 \\
\hline
\end{tabular}

Table 1 shows that the highest proportion of systolic in the intervention group was 140-159 $\mathrm{mmHg}$ of 11 people $(61.1 \%)$ and in the control group of 8 people $(44.5 \%)$; while the highest proportion of diastolic in the intervention group was between $100-109 \mathrm{mmHg}$ by 7 people $(38.9 \%)$ and in the control group between $90-99$ mmHg by 9 people $(50 \%)$.

Table 2. Mean differences of blood pressure on the intervention group.

\begin{tabular}{lccccc}
\hline Measurement & Variable & $\mathrm{N}$ & $\begin{array}{c}\text { Mean } \\
(\mathrm{mmHg})\end{array}$ & SD & P-value \\
\hline Before & Siastole & 18 & 153.61 & 13.91 & \\
After & & 18 & 135.56 & 13.38 & 0.000 \\
Before & Diastole & 18 & 92.78 & 8.95 & \\
After & & 18 & 83.89 & 6.78 & 0.000 \\
\hline
\end{tabular}

Table 2 shows that the average systolic measurement at the first measurement is 153.61 $\mathrm{mmHg}$, and the second measurement is $\mathbf{1 3 5 . 5 6}$ $\mathrm{mmHg}$. There is a significant difference between 
the results of the first and second systolic measurements ( $p$-value $=0.000$ and $\alpha=0.05$ ). The average diastolic measurement in the first measurement is $92.78 \mathrm{mmHg}$, and the second measurement was $83.89 \mathrm{mmHg}$. There is a significant difference between the results of the first and second diastolic measurements ( $p$-value $=0.000$ and $\alpha=0.05$ ).

Most respondents are approximately aged 70-79 years old. Older adults tend to have a higher blood pressure than younger people because physiological function decreases due to the aging process so that many non-communicable diseases occur in old age. The elderly are also susceptible to infectious diseases due to weakened immunity (Ministry of Health, 2013).

Patients with hypertension in this study are mostly women. These are because after turning 55 , around $60 \%$ of older adults who suffer from hypertension are women due to the decrease of estrogen hormone (Pratiwi \& Mumpuni, 2017). Women who are not yet facing menopause, their estrogen plays a role in increasing High-Density Lipoprotein (HDL) that protects blood vessels from damage. As we age, the hormone estrogen decreases so that women are prone to hypertension after menopause. Supported by research where as significant relation between hormonal contraception usage with hypertension incidence (Suryanda, 2017).

Based on the results of blood pressure measurements conducted before the intervention, the average systolic is $140-159 \mathrm{mmHg}$, and the diastolic is $90-99 \mathrm{mmHg}$. After administering self-acupressure intervention, there is a decrease in systolic to $110-130 \mathrm{mmHg}$ and diastolic to $70-80 \mathrm{mmHg}$. There is a significant difference between the results of the first and second systolic measurements ( $p$-value 0.000), and there are significant differences between the results of the first and second diastolic measurements (p-value 0.000) in the elderly group acquire the intervention. Acupressure is done by involving the elderly independently accompanied by family. A decrease in both systolic and diastolic blood pressure occurs after acupressure. This is also in line with research conducted by Majid (2016) explaining that there is a decrease in average systolic and diastolic blood pressure with a p-value (0.001) after administering acupressure for three times. Mustapha's research (2017) states that acupressure interventions can help improve circulation in post-stroke patients.
The results of Afrila, Pristiana, and Erwin (2015) research prove that the administration of a combination of slow stroke back massage and acupressure therapy is proven effective in reducing blood pressure in patients with hypertension. Relaxation is an action that must be performed on every anti-hypertensive therapy. If the blood pressure increases, the relaxed blood vessels will become vasodilation so that it will cause the blood pressure to drop and will slowly return to normal (Muttaqin, 2009). The results of this study are in line with Adam's (2011) study that stimulation to acupressure points can stimulate mast cells to release histamine as a mediator of vasodilation of blood vessels, resulting in increased blood circulation that causes the body to relax and ultimately reduce blood pressure. The existence of various interventions carried out on the decline experienced by the elderly is expected to influence and to give meaningful changes. Inline to the results of research conducted by Prasetyo (2015) that there are significant differences between the cognitive functions of the elderly after taking action memory training.

\section{Conclusion and Suggestion}

Independent acupressure that can be done by the elderly alone with family can significantly reduce systolic blood pressure by $18.05 \mathrm{mmHg}$. Acupressure or emphasis on specific points on the body is one of the non-pharmacological interventions that are efficient and relatively safe because they do not carry out invasive actions.

It is expected that nursing education can be used as learning material in the laboratory and become one of the alternatives or complementary therapies in the community in the management of hypertension in the elderly. For nurses in the community who handle the elderly program can motivate the elderly and families to be able to carry out independent acupressure on the elderly regularly. As a reference material for further research on family experience doing acupressure. The limitation of this study is it only takes one blood pressure measurement for intervention and control group.

\section{Acknowledgements}

This work is supported by Akper Bina Insan Director who gave the golden opportunity doing a lot of research. 


\section{References}

Adam, M., Nurachmah, E., \& Waluyo, A. (2011).Pengaruh Akupresur terhadap Kekuatan Otot dan Rentang Gerak Ekstremitas Atas pada Pasien Stroke Pasca Rawat Inap di RSUP Fatmawati Jakarta. Jurnal Keperawatan Indonesia. Volume 17, No.3, hal 81-87.

Afrila, N., Dewi, A.P., \& Erwin. (2015). Efektifitas Kombinasi Terapi Slow Stroke Back Massage dan Akupresur terhadap Penurunan Tekanan Darah pada Penderita Hipertensi. Jurnal Online Mahasiswa (JOM) Bidang Ilmu Keperawatan Vol 2, No 2 (2015) page. 1299-1307.

Fengge,A.(2012).Terapi Akupresur Manfaat dan Teknik Pengobatan. Yogyakarta: Crop CircleCorp.

Hartono, R.I. W. (2012). Akupresur untuk berbagai penyakit. Yogyakarta: Rapha Publishing.

Japaries, W., Nando, A., Yandy., \& Sulaida. (2016). Gejala Penyakit yang Umum: Akupresur Mandiri untuk Penyakit yang Umum. Jakarta: PT Legacy Utama Kreasindo.

Kemenkes RI. (2013). Gambaran Kesehatan Lanjut Usia di Indonesia. Buletin Jendela Data dan Informasi Kesehatan. Semester I. Jakarta: Kemenkes RI.

Kemenkes. (2014). Panduan Akupresur Mandiri bagi Pekerja di Tempat Kerja. Jakarta.

Kowalski, R. E. (2010).Terapi Hipertensi: Program 8 minggu menurunkan tekanan darah tinggi dan mengurangi risiko serangan jantung dan stroke secara alami. Bandung: Penerbit Qanita.

Kozier,B.,Erb,G.,Berman,A.,\&Snyder,S.J.(2010). Buku Ajar Fundamental Keperawatan: Konsep, Proses, dan Praktik. Edisi 7, Vol.II. Jakarta: EGC.

Majid, Y.A., \& Rini, P.S. (2016). Terapi Akupresur Memberikan Rasa Tenang dan Nyaman serta Mampu Menurunkan Tekanan Darah Lansia. Jurnal Ilmu Kesehatan Vol 1, No 1 (2016): JIKA page. 79-86.

Mustopa, Hermayanti, Y., \& Indrayani, D. (2017). Peningkatan Fungsi Motorik melalui Akupresur pada Klien Pasca Stroke. Jurnal Keperawatan Vol 5, No 2 (2017).

Mutaqqin, A. (2009). Asuhan Keperawatan Klien dengan Gangguan Kardiovaskular dan Hematologi. Jakarta: Salemba Medika.

Prasetyo, H., Nugroho, P., \& Sukrillah, U.A. (2015). Memory Training Anagram terhadap Peningkatan Fungsi Konitif Lansia. Jurnal Riset Kesehatan. Vol. 4, No.3: 798-806.

Purwati, D., Suryani, M.,\& Supriyono, M. (2011). Perbedaan Tekanan Darah Sebelum dan Sesudah Terapi Relaksasi Benson pada Pasien Hipertensi. e.journal.

Rezky, R.A., Hasneli, Y., \& Hasanah, O. (2015). Pengaruh Terapi Pijat Refleksi Kaki terhadap Tekanan Darah pada Penderita Hipertensi Primer. Jurnal Online Mahasiswa: Vol.2. No.2. Oktober 2015. www.portalgaruda.org.

Riskesdas. (2013). Riset Kesehatan Dasar. Jakarta: Badan Penelitian dan Pengembangan Kesehatan Kementerian Kesehatan RI.

Rukayah, S. (2013). Pengaruh Terapi Akupresur Terhadap Mual Muntah Akibat Kemoterapi Pada Anak Usia Sekolah Yang Menderita Kanker Di RS Kanker Dharmais Jakarta. Tesis. Jakarta : Universitas Indonesia.

Saputra, K. (2002). Akupuntur Klinik. Surabaya: University Press.

Savitri, D. (2017). Diam-Diam Mematikan: Cegah Asam Urat dan Hipertensi. Yogyakarta: Healthy.

Suryanda. (2017). Analisis Faktor Resiko Hipertensi Sekunder pada Pengguna Kontrasepsi Aktif di Puskesmas Tanjung Agung. Jurnal Riset Kesehatan, 6 (2): 17-22.

Smeltzer, S. C., \& Bare, B.G. (2013). Buku Ajar Keperawatan Medikal-Bedah Brunner \& Suddarth. Edisi 8. Vol 2. Jakarta: EGC.

Widodo, D.S.D., Hurhayati, Y.,\& Fitriani, R.N. (2014). Pengaruh Terapi Akupresur pada Pasien Hipertensi di Klinik Synergy Mind Health Surakarta. Downloaded from www.digilib.stikeskusumahusada.ac.id. 